International Journal of Pharmaceutics \& Pharmacology

\title{
Evaluation of the Anti-inflammatory Activity and Ulcerogenic Risk of "Sarenta", an Ivorian Herbal Preparation
}

\author{
Effo KE, Djadji ATL, N’Guessan BN, Kouakou SL, Anzoua E, Fatto N, Irié-N'Guessan G and Kouakou- \\ Siransy $N G^{*}$
}

Department of Pharmacology, Clinical Pharmacy and Therapeutics, Faculty of pharmaceutical and biological sciences, University of Félix Houphouët-Boigny, Abidjan - Côte d'Ivoire

Article info

Received 30 November 2018

Revised 20 December 2018

Published 28 December 2018

*Corresponding author: KouakouSiransy N'Doua Gisèle, Department of Pharmacology, Clinical Pharmacy and Therapeutics, Faculty of pharmaceutical and biological sciences, University of Félix Houphouët-Boigny, Abidjan-Côte d'Ivoire, Tel: (00225) 07494409, E-mail: giselekouakou@yahoo.fr

\begin{abstract}
"Sarenta" is an Ivorian herbal preparation used for various purposes such its anti-inflammatory activity. On account of the ulcerogenic side effects of conventional anti-inflammatory drugs and in order to promote African traditional medicine, this study aimed to assess the anti-inflammatory activity and ulcerogenic risk of Sarenta.

The anti-inflammatory activity was evaluated by measuring the decrease in carrageenan-induced paw oedema in rat in acute model by "Sarenta", then in sub-acute model by the decrease of the formation of granuloma induced by cotton pellets implanted subcutaneously in rats. Ulcerogenic risk was assessed by administering "Sarenta" alone to rats that were anesthetized 4 hours later. The ulcerogenic risk on gastric mucosa was evaluated and codified using a magnifying glass.
\end{abstract}

"Sarenta" at $10 \mathrm{mg} / \mathrm{kg}$ and $50 \mathrm{mg} / \mathrm{kg}$ induced a decrease in carrageenaninduced paw oedema in rat with an activity on the acute inflammation above $60 \%$ for the first 3 hours, above $70 \%$ at the 4 th hour and beyond $80 \%$ at the 5th hour. "Sarenta" at the same doses did not affect rats's gastric mucosa, showing a mucous membrane without erosions or petechiae. However, in a sub-acute inflammation model, "Sarenta" did not exhibit an antiinflammatory activity $100 \mathrm{mg} / \mathrm{kg}$ and $200 \mathrm{mg} / \mathrm{kg}$, a non-significant decrease in granuloma formation was recorded at a dose of $200 \mathrm{mg} / \mathrm{kg}$.

In an acute inflammation model, "Sarenta" showed an anti-inflammatory activity with no ulcerogenic risk in animal. This herbal preparation represents an alternative for conventional non-steroidal anti-inflammatory drugs, as far as their ulcerogenic risks. However, in a sub-acute inflammation model, it did not show anti-inflammatory activity. Further investigations should be carried out that could lead to its introduction into anti-inflammatory therapeutic arsenal.

Keywords: Anti-inflammatory; Ulcerogenic risk; Sarenta 
Citation: Effo KE, Djadji ATL, N'Guessan BN, et al. Evaluation of the Anti-inflammatory Activity and Ulcerogenic Risk of "Sarenta", an Ivorian Herbal Preparation. Int J Pharm Pharmacol 2018; 2: 131. doi: $\underline{10.31531 / 2581-3080.1000131}$

\section{Introduction}

In the face of socio-economic and accessibility problems with conventional medicines, more than $80 \%$ of the African population resort to traditional medicine for treatment [1]. Traditional medicine is indeed full of a wide range of remedies used by traditional medicine practitioners for centuries [2]. Moreover, since 1977, WHO is paying a particular attention to traditional medicine for it contributes in achieving the goal of providing primary health care for all $[3,4]$.

In Côte d'Ivoire, the Ministry of Health has integrated traditional medicine in its national health development plan by creating the National Programme for Promoting Traditional Medicine in 2001 with the aim of improving national health coverage.

The purpose of this integration was to achieve tight collaboration between both conventional and traditional medicine practitioners. However, there is little scientific data on traditional medicine practitioners' remedies efficacy and safety. Among this, one can quote "Sarenta" an herbal preparation owned by Mr. Adou Tano Albert, a traditional medicine practitioner wellknown by the Ivorian Ministry of Health.

"Sarenta" is an Ivorian herbal preparation used for various purposes such its anti-inflammatory activity. On account of the ulcerogenic side effects of conventional anti-inflammatory drugs and in order to promote African traditional medicine, this study was designed to assess the anti-inflammatory activity and ulcerogenic risk of "Sarenta".

\section{Materials and Methods}

\section{The remedy "Sarenta"}

"Sarenta" is a brownish aqueous suspension with a characteristic odour and a bitter taste. It was made from root barks and woody vines of various plants. The preparation was performed in a traditional way, packaged and sold in plastic bottles (Figure 1). This aqueous suspension was dried in an oven at $60^{\circ} \mathrm{C}$ for 36 hours to obtain dry residue which was used to prepare a range of concentrations in this study.

\section{Solvents and Chemicals}

For the carrageenan induced paw oedema test:

- Normal saline

- Indometacin (Indocid ${ }^{\circledR} 100$ mg Hac pharma capsule)
- $1 \%$ Carrageenan

For the cotton pellet test:

- Normal saline

- Diclofenac (TEVA)

- Ether (GIFRER)

Study of the anti-ulcerogenic effect:

- Normal saline

- Indometacin (Indocid $^{\circledR} 100 \mathrm{mg}$ Hac pharma capsule)

- $\quad$ Ether (GIFRER)

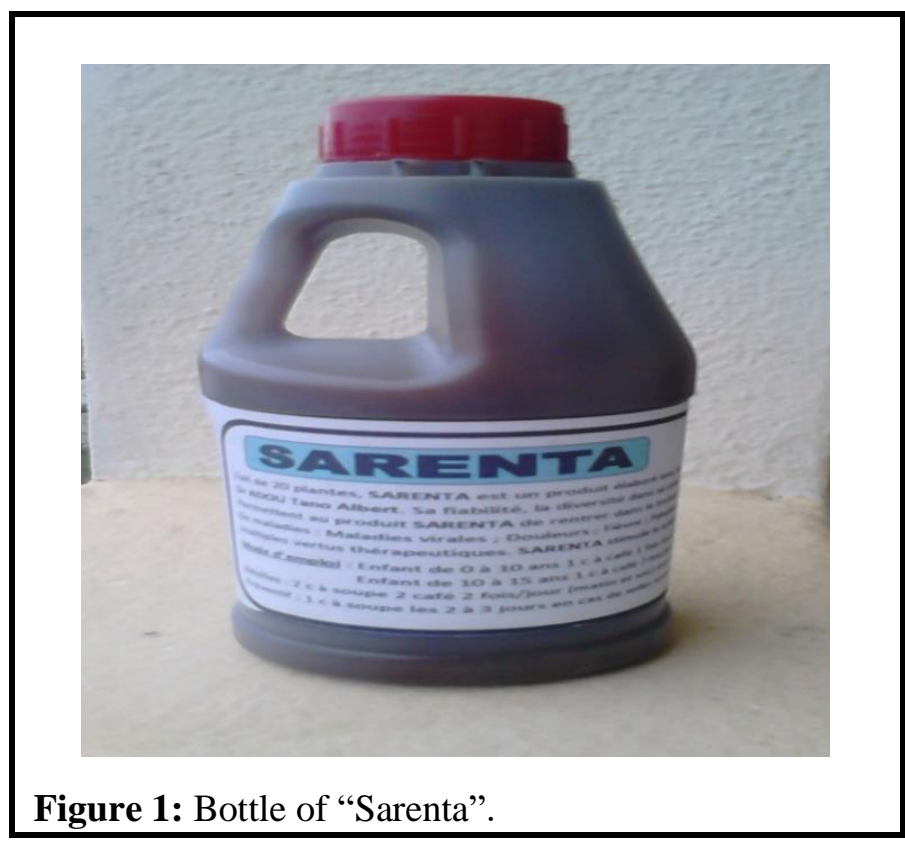

Animal Material

Adult Wistar rats of both sexes weighing between 120 and $250 \mathrm{~g}$ from the animal husbandry of the Department of Pharmacology, Faculty of Pharmaceutical and Biological Sciences of the University of Félix Houphouët-Boigny (Abidjan, Côte d'Ivoire) were used. They were kept in standard temperature conditions (26 $\pm 1{ }^{\circ} \mathrm{C}$ ), 12 hours of light/dark cycle, fed, with free access to water ad libitum.

\section{Study of in vivo anti-inflammatory activity on carrageenan-induced paw oedema in the rat}

The process was described by Winter et al. [5]. Animals were divided into 4 groups comprising six (6) rats in each group and treated by oral route as follows: Group 1 representing the positive control was treated with normal saline $(10 \mathrm{ml} / \mathrm{kg})$; groups 2 and 3 were treated 
Citation: Effo KE, Djadji ATL, N'Guessan BN, et al. Evaluation of the Anti-inflammatory Activity and Ulcerogenic Risk of "Sarenta", an Ivorian Herbal Preparation. Int J Pharm Pharmacol 2018; 2: 131. doi: $\underline{10.31531 / 2581-3080.1000131}$

with "Sarenta" at doses of $10 \mathrm{mg} / \mathrm{kg}$ and $50 \mathrm{mg} / \mathrm{kg}$ respectively; group 4 representing the negative control was treated with indomethacin at a dose of $10 \mathrm{mg} / \mathrm{kg}$.

One (1) hour after administration, the oedema was induced by a sub plantar injection of $50 \mu \mathrm{l}$ freshly prepared $1 \%$ suspension of carrageenan. Paw volume was measured at $0 \mathrm{~h}, 1 \mathrm{~h}, 2 \mathrm{~h}, 3 \mathrm{~h}, 4 \mathrm{~h}$, and $5 \mathrm{~h}$ after carrageenan injection using a digital micrometre and the percentage of inhibition of the oedema was determined. The inflammation (\% I), was calculated according to the following formula [6]:

\section{$\% \mathrm{I}=(\mathrm{Tt}-\mathrm{To}) / \mathrm{To} \times 100$}

To: Initial paw volume of each animal

Tt: Paw volume at time $t$ of each animal

In addition, the anti-inflammatory effect (\% A) was calculated according to the formula below [6]:

$\% \mathrm{~A}=(1-\% \mathrm{Ie} / \% \mathrm{Ic}) \times 100$

$\%$ Ic: Mean value of inflammation in the control group

\%Ie: Mean value of inflammation experimental groups.

\section{In vivo anti-inflammatory activity on cotton pellet- induced granuloma formation in rats}

The method was described by Swingle and Shideman [7]. 30 male rats were divided into 5 groups of 6 rats each. Two (2) sterilized cotton pellet granuloma models weighing $24 \mathrm{mg}$ were implanted by sub-cutaneous route, one on each side of all rat abdomens after being anesthetized by ether through inhalation.

Subsequently, group 1 (positive control) was treated with normal saline. Groups 2, 3 and 4 were treated by "Sarenta" at doses of $67 \mathrm{mg} / \mathrm{kg} /$ day (recommended dose by the traditional medicine practitioner), $100 \mathrm{mg} / \mathrm{kg} /$ day and $200 \mathrm{mg} / \mathrm{kg} /$ day respectively. Group 5 was treated with diclofenac at a dose of $25 \mathrm{mg} / \mathrm{kg} / \mathrm{day}$. All animals were treated for 7 consecutive days. On day 8, each rat was anesthetized by ether inhalation and the implanted pellets were removed and dried at $60^{\circ} \mathrm{C}$ for 24 hours. Dry weights of the granuloma were recorded, and the percentage inhibition of the granuloma formation of tested compounds was calculated according to the following formula:

\section{$\mathrm{P}=(\mathrm{WgrC}-\mathrm{WgrT}) / \mathrm{WgrC} \times 100$}

WgrC: Represents the mean weight of the control granulomatous tissue
WgrT: Represents the mean weight of tested granulomatous tissue

\section{Assessment of the ulcerogenic risk of "Sarenta"}

The process was described by Alam et al. [8]. Thirty (30) rats were divided into 5 groups of 6 rats each and fasted for 48 hours. At the end of the 48 hours fasting, they were treated with oral route as follows: Group 1 (control) was treated with normal saline at $10 \mathrm{ml} / \mathrm{kg}$. Groups 2 and 3 were treated with "Sarenta" at respective doses of $10 \mathrm{mg} / \mathrm{kg}$ and $50 \mathrm{mg} / \mathrm{kg}$. Groups 4 and 5 were treated with indomethacin at doses of $10 \mathrm{mg} / \mathrm{kg}$ and 50 $\mathrm{mg} / \mathrm{kg}$ respectively.

Four (4) hr later, rats were anesthetized through ether inhalation and the stomach of each rat was excised, cut open along the large curve and rinsed with saline water. It was then examined using a magnifying glass and the intensity of gastric lesions was evaluated using a modified scoring system described by Adami et al. [9]: 0 , no lesions; 0.5 , slight hyperemia or $\leq 5$ petechiae; 1 , $\leq 5$ erosions $\leq 5 \mathrm{~mm}$ in length; $1.5, \leq 5$ erosions $\leq 5 \mathrm{~mm}$ in length and many petechiae; $2,6-10$ erosion $\leq 5 \mathrm{~mm}$ in length; 2,5, 1-5 erosions $<5 \mathrm{~mm}$ in length; $3,>5-10$ erosions $>5 \mathrm{~mm}$ in length; $3,5,>10$ erosions $>5 \mathrm{~mm}$ in length; $4,1-3$ erosions $\leq 5 \mathrm{~mm}$ in length and $0.5-1$ $\mathrm{mm}$ in width; $4.5,4-5$ erosions $\leq 5 \mathrm{~mm}$ long and 0.5 to $1 \mathrm{~mm}$ wide; $5,1-3$ erosions $>5 \mathrm{~mm}$ long and 0.5 to 1 mm wide; 6,4 or 5 grade 5 lesions; $7, \geq 6$ grade 5 lesions; 8 , complete lesion of the mucosa with hemorrhage.

The mean ulcer score was calculated for each group. The protection rate was calculated using the following formula:

\section{(Control Score - Test Score) / Control Score $\times 100$}

\section{Statistical Analysis}

The results were expressed as Mean \pm standard deviation. The statistical analysis was performed by the SPSS v 18.0 software. The graphs were performed using the Graph Pad Prism 7.00 software. Means comparison was made using the Wilcoxon non-parametric test. A p value $<0.05$ was considered as statistically significant.

\section{Results}

Anti-inflammatory activity of "Sarenta" on carrageenan-induced paw oedema in rat

The oedema caused by carrageenan injection in rat paws gradually increased to its maximum 4 hours after injection. Indomethacin at a dose of $10 \mathrm{mg} / \mathrm{kg}$ and "Sarenta" at doses of $10 \mathrm{mg} / \mathrm{kg}$ and $50 \mathrm{mg} / \mathrm{kg}$ 
Citation: Effo KE, Djadji ATL, N'Guessan BN, et al. Evaluation of the Anti-inflammatory Activity and Ulcerogenic Risk of "Sarenta", an Ivorian Herbal Preparation. Int J Pharm Pharmacol 2018; 2: 131. doi: $\underline{10.31531 / 2581-3080.1000131}$

significantly reduced carrageenan-induced inflammation during experiment $(\mathrm{P}<0.01)$. The inflammation percentage $(\% \mathrm{I})$ and the anti- inflammatory activity percentages (\%A) were calculated and recorded in Table 1.

Table 1: Effect of "Sarenta" on the Percentage inhibition of carrageenan induced hind paw oedema in rat.

\begin{tabular}{|c|c|c|c|c|c|c|c|c|c|c|c|}
\hline \multirow{3}{*}{ Group } & \multirow{3}{*}{$\begin{array}{c}\text { Dose } \\
(\mathrm{mg} / \mathrm{kg})\end{array}$} & \multicolumn{10}{|c|}{ Time after injection of carrageenan } \\
\hline & & \multicolumn{2}{|c|}{1 hours } & \multicolumn{2}{|c|}{2 hours } & \multicolumn{2}{|c|}{3 hours } & \multicolumn{2}{|c|}{4 hours } & \multicolumn{2}{|c|}{5 hours } \\
\hline & & $(\mathrm{I} \%)$ & $(\mathrm{A} \%)$ & $(\mathrm{I} \%)$ & $(\mathrm{A} \%)$ & $(\mathbf{I \%})$ & $(\mathrm{A} \%)$ & $(\mathbf{I} \%)$ & $(\mathrm{A} \%)$ & $(\mathbf{I} \%)$ & $(\mathrm{A} \%)$ \\
\hline Control & & $\begin{array}{c}23.68 \\
\pm 6.68\end{array}$ & & $\begin{array}{c}24.1 \pm \\
3.37\end{array}$ & & $\begin{array}{c}24.45 \pm \\
4.98\end{array}$ & & $\begin{array}{l}24.95 \\
\pm 7.36\end{array}$ & & $\begin{array}{r}24.63 \\
\pm 6.62\end{array}$ & \\
\hline $\begin{array}{l}\text { Indomet } \\
\text { acin }\end{array}$ & 10 & $\begin{array}{r}16.95 \\
\pm 125\end{array}$ & 28.4 & $\begin{array}{r}15.04 \\
\pm 3.99\end{array}$ & 39.93 & $\begin{array}{c}11.51 \pm \\
3.81\end{array}$ & 52.91 & $\begin{array}{c}8.37 \pm \\
3.82\end{array}$ & 66.42 & $\begin{array}{r}10.57 \\
\pm 3.04\end{array}$ & 55.84 \\
\hline Sarenta & 10 & $\begin{array}{l}4.24 \pm \\
4.17^{* *}\end{array}$ & $82.08^{* * *}$ & $\begin{array}{l}9.03 \pm \\
3.59^{* *}\end{array}$ & $63.58^{* *}$ & $\begin{array}{l}8.25 \pm \\
4.83^{*}\end{array}$ & $66.25^{*}$ & $\begin{array}{c}6.45 \pm \\
4.52^{*}\end{array}$ & $74.13^{*}$ & $\begin{array}{l}4.88 \pm \\
4.25^{* *}\end{array}$ & $\begin{array}{c}80.16 \\
* *\end{array}$ \\
\hline Sarenta & 50 & $\begin{array}{l}8.3 \pm \\
3.20^{* * *}\end{array}$ & $64.93^{* *}$ & $\begin{array}{l}8.39 \pm \\
3.67^{* *}\end{array}$ & $66.17^{* *}$ & $\begin{array}{l}8.66 \pm \\
3.05^{*}\end{array}$ & $64.55^{*}$ & $\begin{array}{l}6.17 \pm \\
2.44^{*}\end{array}$ & $75.27^{*}$ & $\begin{array}{l}3.03 \pm \\
2.62^{* *}\end{array}$ & 87.66 \\
\hline
\end{tabular}

Note: The values represent percentages of inflammation (I \%) and percentages of anti-inflammatory activity (A \%), $3=6$ for each group. "Wilcoxon test: $p<0.01$ compared to indomethacin, ${ }^{* *}$ Wilcoxon test: $p<0.001$ compared to indomethacin.

However, "Sarenta" seemed to have a higher antiinflammatory activity than indomethacin $(\mathrm{p}<0.001)$. In the group of rats treated with "Sarenta" at a dose of 10 $\mathrm{mg} / \mathrm{kg}$, the anti-inflammatory activity appears to be greater the first hour after carrageenan injection than in the group of rats treated at a dose of $50 \mathrm{mg} / \mathrm{kg}$ (p $<0.001)$. The anti-inflammatory activity was then equivalent to 2-hour, 3-hour and 4-hour. However, 5 hours after induction of oedema by carrageenan, a higher activity was observed at a dose of $50 \mathrm{mg} / \mathrm{kg}$ (p $<0.001)$.

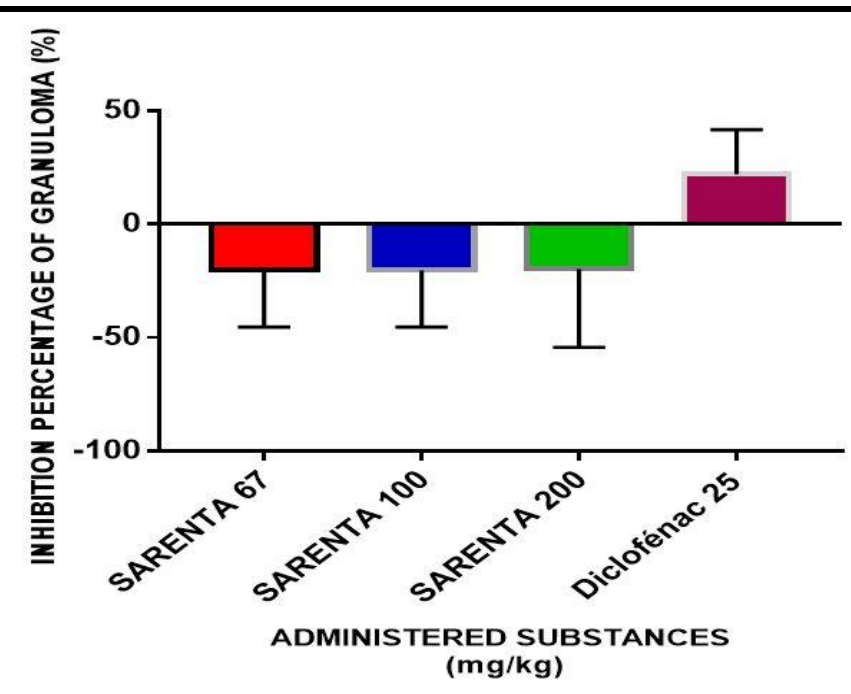

Figure 2: Inhibition percentage of granuloma formation by "Sarenta".

\section{Anti-inflammatory activity on cotton pellet-induced granuloma formation in rats}

In a subacute inflammation model, "Sarenta" at doses of $67 \mathrm{mg} / \mathrm{kg} /$ day, $100 \mathrm{mg} / \mathrm{kg} /$ day and $200 \mathrm{mg} / \mathrm{kg} /$ day did not exhibit an anti-inflammatory effect as shown in Figure 2. Inflammation continued during the 7 days of treatment while diclofenac at a dose of $25 \mathrm{mg} / \mathrm{kg}$ inhibited granuloma formation at about $22 \%$.

Table 2: Anti-ulcerogenic effect of "Sarenta",

\begin{tabular}{|c|c|c|}
\hline Substance & Dose (mg/kg) & Score \\
\hline Distilled water & - & 0 \\
\hline Sarenta & 10 & 0 \\
\hline Sarenta & 50 & 0 \\
\hline Indometacin & 10 & $0.83 \pm 0.21^{*}$ \\
\hline Indometacin & 50 & $1.96 \pm 0.37^{* *}$ \\
\hline $\begin{array}{l}\text { Note: The values represent ulcer injury scores, } \mathrm{n}=6 \\
\text { for each group, *Wilcoxon test: } \mathrm{p}<0.01 \text { compared to } \\
\text { negative control group, }{ }^{* *} \text { Wilcoxon test: } \mathrm{p}<0.001 \\
\text { compared to negative control group. }\end{array}$ \\
\hline
\end{tabular}

\section{Ulcerogenic risk of "Sarenta"}

Sarenta" at doses of $10 \mathrm{mg} / \mathrm{kg}$ and $50 \mathrm{mg} / \mathrm{kg}$ did not cause petechiae or gastric mucosa erosion in rats (Figure 3 and Table 2), while indomethacin at the same doses caused ulcerations with an increase in injury at a dose of $50 \mathrm{mg} / \mathrm{kg}$ (Figures 4 and 5, Table 2). 
Citation: Effo KE, Djadji ATL, N'Guessan BN, et al. Evaluation of the Anti-inflammatory Activity and Ulcerogenic Risk of "Sarenta", an Ivorian Herbal Preparation. Int J Pharm Pharmacol 2018; 2: 131. doi: $\underline{10.31531 / 2581-3080.1000131}$
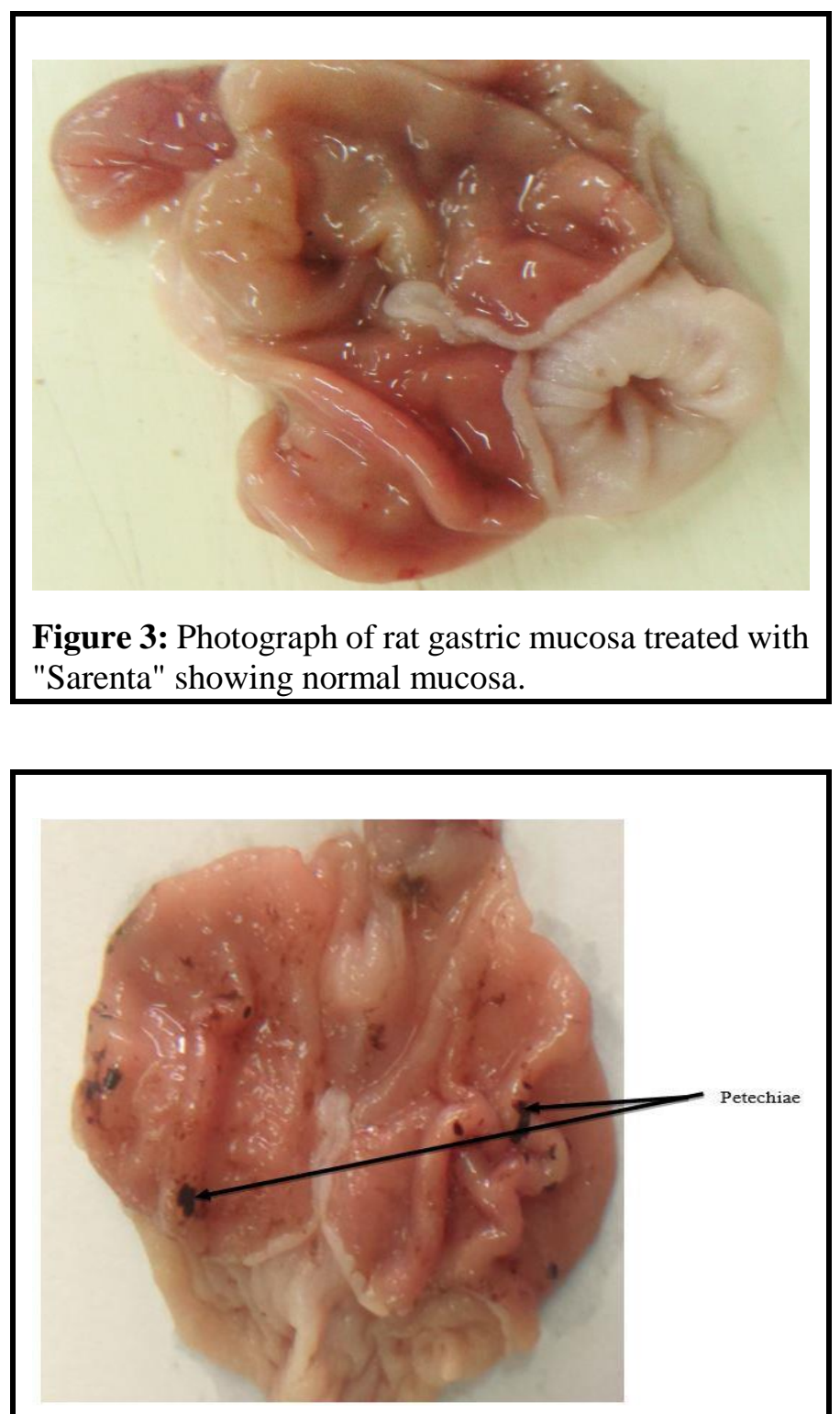

Figure 4: Photograph of rat gastric mucosa treated with indomethacin at a dose of $10 \mathrm{mg} / \mathrm{kg}$ showing petechiae.

\section{Discussion}

This study aimed to assess the anti-inflammatory activity and ulcerogenic risk of an herbal preparation "Sarenta", made of root barks and woody vines of various plants, traditionally used for more than twenty years in Côte d'Ivoire.

The study of the anti-inflammatory activity of "Sarenta" was motivated by the studies of Kouakou-Siransy et al. [10] which showed the analgesic activity, quality and safety use of this remedy. Indeed, Kouakou-Siransy et al. [10] demonstrated that "Sarenta" in addition to its analgesic activity, could have a potential antiinflammatory activity by the formalin test, a nonspecific test for studying anti-inflammatory activity
[11]. The Carrageenan-induced paw oedema in rat test used in this study was a more specific test to study the anti-inflammatory activity. Carrageenan-induced inflammation is an acute and highly reproducible inflammatory model.

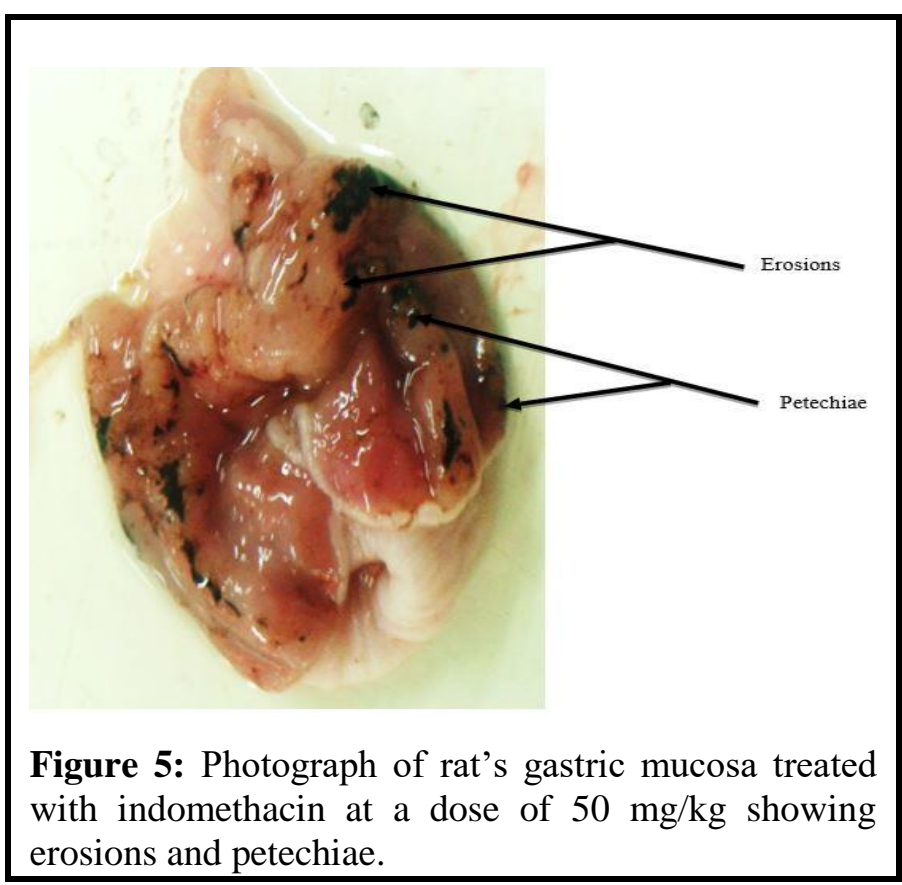

Cardinal signs of inflammation appear immediately after injection under the aponeurosis plantar of rat, resulting from pro-inflammatory agent actions [12]. The development of oedema is a two-phase event: the early phase ( 0 to $2.5 \mathrm{hr}$ ) involves the release of inflammatory mediators such as histamine, serotonin and bradykinin; the late phase ( 3 to $6 \mathrm{hr}$ ), is associated with the release of prostaglandins $[12,13]$.

In this study, "Sarenta" and indomethacin significantly inhibited paw oedema in rat during both phases of carrageenan-induced inflammation, indicating that "Sarenta", as well as indomethacin, block the release of histamine and serotonin during the initial phase. They also prevent the release of some inflammation mediators by blocking the action of prostaglandins during the late phase. However, indomethacin has toxic effects because it inhibits isoenzymes responsible for prostaglandin production, promoting haemorrhagic ulceration in rats by oxidative stress and a decrease in prostaglandin production [14]. Moreover, non-selective cyclooxygenase inhibitors may cause kidney damage and more selective cyclooxygenase-2 inhibitors increase the risk of cardiovascular disease $[15,16]$. There is therefore an urgent need for effective and welltolerated anti-inflammatory drugs. "Sarenta" at doses of $10 \mathrm{mg} / \mathrm{kg}$ and $50 \mathrm{mg} / \mathrm{kg}$, did not cause any gastric 
Citation: Effo KE, Djadji ATL, N'Guessan BN, et al. Evaluation of the Anti-inflammatory Activity and Ulcerogenic Risk of "Sarenta", an Ivorian Herbal Preparation. Int J Pharm Pharmacol 2018; 2: 131. doi: 10.31531/2581-3080.1000131

damage and could be a good alternative in the treatment of acute inflammation.

This anti-inflammatory activity of "Sarenta" could be explained by the presence in this herbal preparation of plants such as Ocimum gratissimum, Cassia occidentalis and Ageratum conyzoides. Indeed, various studies have been carried out on the analgesic activity of these plants using the formalin test and have shown their potential to inhibit the inflammatory phase of pain [17-19]. In addition, "Sarenta" showed an antiinflammatory activity at doses of 10 and $50 \mathrm{mg} / \mathrm{kg}$, while each plant quoted above showed their antiinflammatory activity at higher doses. These doses ranged from 150 to $300 \mathrm{mg} / \mathrm{kg}$ for Cassia occidentalis [17], $2000 \mathrm{mg} / \mathrm{kg}$ for Ageratum conyzoides [18] and from 200 to $800 \mathrm{mg} / \mathrm{kg}$ for Ocimum gratissimum [19]. The low dose of "Sarenta" could be explained by a synergy action between active compounds found in this herbal preparation.

However, in subacute inflammation models, "Sarenta" at doses of $67 \mathrm{mg} / \mathrm{kg} /$ day, $100 \mathrm{mg} / \mathrm{kg} /$ day and 200 $\mathrm{mg} / \mathrm{kg} /$ day for 7 days did not seem to possess an antiinflammatory activity. Indeed, in the formation of granulomas induced by cotton pellets, responses can be divided into three phases. The first phase, called transudative, from 0 to 3 hours after the implantation of cotton pellets, is defined as a leakage of liquid into the blood vessels caused by an increase in vascular permeability. The second phase, known as the exudative phase, from 3 to 72 hours after the implantation of cotton pellets, is defined as the influx of low molecular weight proteins from blood circulation around the granuloma, caused by intensive maintenance of vascular permeability change. The proliferative final phase, from day 3 to day 6 , is defined as the production of granulomatous tissues caused by the continuous release of a pro-inflammatory mediator $[7,20]$. According to Swingle and Shideman [7], steroids could significantly inhibit the transudative and proliferative phases.

According to Swingle and Shideman [7], steroids could significantly inhibit the transudative and proliferative phases. NSAIDs such as indomethacin, aspirin and diclofenac may have moderate effects. It seems that "Sarenta" remedy does not have a steroid-like effect and therefore does not possess an anti-inflammatory activity in the subacute inflammation model. However, Tamarindus indica one of the plants used for the preparation of "Sarenta", showed an anti-inflammatory activity in a subacute inflammation model at doses of 300 and $600 \mathrm{mg} / \mathrm{kg}$ [21]. The active compounds of the other plants might have antagonized this effect or should higher doses of "Sarenta" be used to exhibit the anti-inflammatory effect in a subacute inflammation model? Further investigations need to be undertaken in this regard.

\section{Conclusion}

"Sarenta" showed an anti-inflammatory activity with no ulcerogenic risk in animal in an acute inflammation model. This herbal preparation represents an alternative for conventional non-steroidal anti-inflammatory drugs, in the face of their ulcerogenic risks. However, in a subacute inflammation model, it did not show antiinflammatory activity. Further investigations should be carried out on "Sarenta" in order to use it as an antiinflammatory drug.

\section{Conflict of Interest}

None Declared.

\section{Funding}

None Declared.

\section{References}

1. World Health Organization. Progress report on decade of traditional medicine in the African region. WHO Regional Office for Africa 2011; pp: 6.

2. Adjanohoun EJ et Aké-Assi L. Contribution to the census of medicinal plants of Ivory Coast. Université d'Abidjan, Abidjan, 1979; 357.

3. World Health Organization. Alma-Ata: Primary health care. USSR 6.-12.9, World Health Organization, Geneva, Switzerland 1978.

4. World Health Organization. WHO Traditional Medicine Strategy: 2014-2023. Geneva, Switzerland 2013; 76.

5. Winter CA, Risley EA, Nuss CW. Carrageenaninduced oedema in hind paw of rats-an assay for anti-inflammatory drugs. Proceedings of Society Experimental Biology Medicine 1962; 111: 544Ŕ547.

6. Delporte C, Bakhouse N, Erazo S, et al. Analgesic anti-inflammatory properties of Proustia pyrifolia. J Ethnopharmacol 2005; 99: 119-124.

7. Swingle K, Shideman F. Phases of the inflammatory response to subcutaneous implantation of a cotton pellet and their modification by certain anti-inflammatory agents. J Pharmacol and Exp Ther 1972; 183: 226-234.

8. Alam S, Asad M, Asdaq SMB, et al. Antiulcer activity of methanolic extract of Momordica 
Citation: Effo KE, Djadji ATL, N'Guessan BN, et al. Evaluation of the Anti-inflammatory Activity and Ulcerogenic Risk of "Sarenta", an Ivorian Herbal Preparation. Int J Pharm Pharmacol 2018; 2: 131. doi: $\underline{10.31531 / 2581-3080.1000131}$

charantia L in rats. J Ethnopharmacol 2009; 123: 464-469.

9. Adami E, Marazzi-Uberti E, Turba C. Pharmacological research on gefarnate, a new synthetic isoprenoid with an anti-ulcer action. Arch Int Pharmacodyn Ther 1964; 58: 1780-1783.

10. Kouakou-Siransy G, Effo KE, Irie-Nguessan G et al. Analgesic efficacy, quality and safety of "Sarenta": An herbal preparation from ivorian traditional medicine. Int J Pharmacol 2017; 13: 257 265.

11. Tjolsen A, Berge OG, Hunskaar S, et al. The formalin test: An evaluation of the method. Pain 1992; 51: 5-17.

12. Yi T, Zhao ZZ, Yu ZL, et al. Comparison of the anti-inflammatory and anti-nociceptive effects of three medicinal plants known as "Snow Lotus" herb in traditional Uighur and Tibetan medicines. J. Ethnopharmacol 2010; 128: 405-411.

13. Habib M, Waheed I. Evaluation of anti-nociceptive, anti-inflammatory and antipyretic activities of Artemisia scoparia hydro methanolic extract. J Ethnopharmacol 2013; 145: 18-24.

14. Utsumi H, Yasukawa K, Soeda $T$, et al. Noninvasive mapping of reactive oxygen species by in vivo electron spin resonance spectroscopy in indomethacin-induced gastric ulcers in rats. $\mathbf{J}$ Pharmacol Exp Ther 2006; 317: 228-235.

15. Mukherjee D, Nissen SE, Topol EJ. Risk of cardiovascular events associated with selective COX-2 inhibitors. JAMA 2001; 286: 954-959.

16. Sommer C, Birklein F. Fighting off pain with resolvins. Nat Med 2010; 16: 518-520.

17. Sini KR, Karpakavalli M, Sangeetha PT. Analgesic and antipyretic activity of Cassia occidentalis Linn. World Appl Sci J 2010; 11: 1216-1219.

18. Rahman MA, Akter N, Rashid H, et al. Analgesic and anti-inflammatory effect of whole Ageratum conyzoides and Emilia sonchifolia alcoholic extracts in animal models. Afr J Pharm Pharmacol 2012; 6: 1469-1476.

19. Ajayi AM, Tanayen JK, Ezeonwumelu JOC, et al. Anti-inflammatory, anti-nociceptive and total polyphenolic content of hydroethanolic extract of Ocimum gratissimum L. leaves. Afr J Med Sci 2014; 43: 215-224.

20. Sarraf P, Sneller M. Pathogenesis of Wegener's granulomatosis: Current concepts. Exp Rev Mol Med 2005; 7: 1-19.

21. Bandawane DEEPT, Mayuri H, Ashish M, et al. Evaluation of anti-inflammatory and analgesic activity of Tamarind (Tamarindus indica L) seeds. Int J Pharm Sci 2013; 5: 623-629.

This manuscript was peer-reviewed

Mode of Review: Single-blinded

Academic Editor: Dr. Syed Sarim Imam

Copyright: (02018 Effo KE, et al. This article is distributed under the terms of the Creative Commons Attribution 4.0 International License (http://creativecommons.org/licenses/by/4.0/), which permits unrestricted use, distribution, and reproduction in any medium, provided you give appropriate credit to the original author(s) and the source, provide a link to the Creative Commons license, and indicate if changes were made. 